\title{
Regional Cooperation in Dealing with Environmental Protection. E-government and Sustainable Development in Andean Countries
}

\author{
Zanna Aniscenko ${ }^{1}$, Andrés Robalino-López², Tomás Escobar Rodríguez ${ }^{3}$, \\ Bernabé Escobar Pérez ${ }^{4}$ \\ University of Seville, Seville-Spain ${ }^{1}, z a n n a . a n i s c e n k o @ g m a i l . c o m$, \\ Escuela Politécnica Nacional, Quito-Ecuador ${ }^{2}$, andres.robalino@epn.edu.ec, \\ University of Huelva, Huelva-Spain ${ }^{3}$, tescobar@uhu.es, \\ University of Seville, Seville-Spain ${ }^{4}$, bescobar@us.es
}

\begin{abstract}
E-government for Sustainable Development is one of international cooperation strategy in dealing with environmental protection and ecological problems through enhanced citizen participation, better access and quality of services in order to achieve Green Governments. In this context, some countries are supported by international assistance to achieve this goal with benchmarking and benchlearning approaches. This research contributes to explain the relationship between improvements in governance influences in economic, social and environmental development and how such regional cooperation on the development of national information and communication technology (ICT) strategies and programs is related to E-government and Sustainable Development. This comparative study of Andean countries takes a Rational Neo-institutionalist perspective to look at longitudinal changes in these developing countries. Quantitative data such as E-government index is combined with qualitative information from reports and documents in order to empirically examine effects of e-government on sustainable development in these countries. The findings show that the strategies adopted by Ecuador have significantly contributed to its location within the references in progress of $E$ government and Sustainable Development in the region. The research suggests that E-government development has positive effects on better governance and sustainable development of Andeans countries. Advancement on E-government is not only a trait of developed countries but also serves as an enabler for sustainable development of developing countries.
\end{abstract}

Keywords: Andean countries, e-government, sustainable development.

\section{INTRODUCTION}

The United Nations (UN) and the World Bank (WB) conduct studies to identify countries' positioning on a wide range of characteristics, including factors such as information and communication technology, governance, economic growth, sustainable development, among others. These studies are carried out taking into account measurable factors within a comparative analysis between countries, which allows not to isolate the evaluation in a subjective and individual way and obtain results based on the region's environment in order to channel cooperation strategies among countries.

In order to maximize the acceptability of the results to the weights assigned in each study, classifications are based on criteria that are clearly understood and supported by regional realities that facilitate a comparative measurement and identify the strategies to be included and the applicability for each of nations as good practices to follow.

E-Government comprises one of the important factors of measurement of development of a country, for this reason the UN dedicates efforts to carry out a survey of information and have an analysis that allows to see the improvements developed in each country with the purpose of generating a strengthening Cooperation between nations in order to benefit the government-citizen relationship through technology [1].

Latin America countries promote strategies of change within the public administration in order to bring the government closer to the citizenry and the efforts undoubtedly mobilize several strategic sectors of the countries such as social assistance, education, health, production, among others; Improving international standards of service to the citizen and raising the quality of life of people in accordance with 
the objectives of the so-called Sustainable Development [2].

In recent years, proposals for improvement in public management have guided the decisions of governments towards innovation within platforms for access to information and to facilitate the operation of services to citizens. Some of the meetings between representatives of the member countries of the UN, are presented with collaborative approaches with exchange of experiences that support the innovation of public management at the global level [1], [2].

E-government for Sustainable Development is one of international cooperation strategy in dealing with environmental protection and ecological problems through enhanced citizen participation, better access and quality of services in order to achieve Green Governments [3], [4], [5]. Governments are finding new ways to effectively create public value through innovative, effective, inclusive, collaborative, open and citizen oriented service delivery and public policy decision-making leveraging the potential of modern technologies such as: i) Social Sustainability for example the Cyber Agriculture Wiki of Department of Agriculture in Sri Lanka [6]. Other initiatives are: E-education, E-health services, Security, Transportation, Community planning, Inclusive social safety nets, Services to vulnerable groups, Welfare networks, Youth engagement, and Silver innovation. ii) Economic Sustainability for example the Gov.uk of Government Digital Service in United Kingdom [7]. Other initiatives are: Online integrated business registration, Easy property registration systems, Open data licensed for commercial use, Easy tax payment systems, Innovative agricultural programmers, and Employment opportunities portals. iii) Environmental Sustainability for example the Eco Mileage Program of Seoul Metropolitan Government [8]. Other initiatives are: My Environment, Citizenparticipating, Greenhouse emissions, Monitor energy, water consumption for savings, Green procurement, Disaster management.

Concerning the enhancement of the quality of governmental system services globally leads people increasingly have greater decision-making and spaces where experiences are disclosed and based on the services or products received and not only in reference to the private sector [9]. This has required the restructuring of the governmental apparatus and with it also the implementation of reforms in public administration and the introduction of an evaluation scheme of management associated with sustainable development in most countries worldwide [10].

The experience of the implementation of egovernment in many developed countries, for instance, in Korea, United Kingdom, Denmark, France, Sweden, among other, show that many of the strategies implemented by these countries are acceptable and can be an example to follow for other nations in order to strengthen the sustainable development of the population [11], [12].

E-government Development Index (EGDI) established by the United Nations, is a reference of measurement that evaluates the attempts that member countries do in their objective to transform and revitalize public management leading results towards greater efficiency, transparency and accountability [13], [14].

Latin-American countries are experiencing stages of transformation product of series of strategies for improving EGDI showing that there is a trend in the region to improve the quality of public administration and the adoption of e-government in the institutional framework of the State [15].

Related to the Andean countries economic (GDP per capita) and environmental (CO2 emissions) situation, the official figures [16] indicate that Colombia, Ecuador and Peru show a similar trend, and the three almost reach the world average of the GDP per capita $(13,679$ USD-PPP constant 2011 international) in the studied period. In regard to the emissions these three countries also are under the world average ( $0.36 \mathrm{~kg}$ per $2011 \mathrm{PPP}$ USD of GDP). At the time, as is known, Venezuela's enormous wealth of natural resources (petroleum) makes it one of the major economies in the region, with a GDP per capita higher than the world average (16,953 USDPPP constant 2011 international), but also this country has the highest emission value of the region (0,37 kg per 2011 PPP USD of GDP) and, finally, Bolivia, which has been historically the least developed country in the region, has a GDP per capita of 5,665 USD-PPP constant 2011 international, which is less than half of the world average value and the second higher emission value of the region $(0,30 \mathrm{~kg}$ per 2011 PPP USD of GDP) [17].

This work tries to analyze how e-government is developed in the Andean countries and its impacts over sustainable development in these countries. The studied period is from 2008 to 2015 taking into account the factor of measurement used by the UN EGDI and social, economic and environmental WB indicator.

\section{II.MATERIALS AND METHODS}

The first stage of this study includes a review of articles and a research conducted in areas of egovernment international organizations like the United Nations Economic Commission for Latin America and the Caribbean (ECLAC), studies about the Organization of American States (OAS) and various publications concerning e-government in the Andeans countries in order to arrive at a better understanding of the economic and social conditions of these countries as well as their environment impacts. The basis of the study documents corresponds to the biennial reports published by UNDESA [13]. United Nations E-Government 
Survey 2010 [18], United Nations E-Government Survey 2012 [15], Nations E-Government Survey 2014 [19] and Nations E-Government Survey 2016 [20]. In addition, a review of main Web portals and digital platforms of public institutions in the study group was made.

This study tries to investigate how the development of e-government affects the sustainable development of the Andeans Regions. Therefore, the conceptual framework is organized by the following broad aspects of development: governance (EGDI), economy (GDP per capita), society (CPIA policy and institutions for environmental sustainability and public sector management and institutions cluster average) and environment sustainability (CO2 emissions).
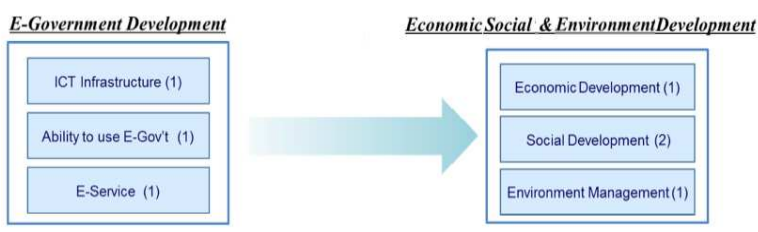

Fig. 1. Conceptual framework of E-Government Development and Economic, Social and Environmental Development

E-government impacts on national development as shown in Figure 1. First, the development of egovernment has direct effects on the development of economy, society and environment management of a state.

The second stage of the study included a statistical test of significance among the effects of egovernment on sustainable development of Andeans countries, the researchers conducted correlation analysis, covering the data of five countries (Bolivia, Colombia, Ecuador, Peru and Venezuela) from 2008 to 2015, corresponding to the periods 2008-2009 (P1), 2010-2011 (P2), 2012-2013 (P3) and 2014-2015 (P4).

\section{A. Measurement of e-government development}

The research approach adopts the EGDI of the UN E-Government Surveys as independent variables. According to the UN E-Government Surveys, the level of e-government development can be assessed in three areas or sub-indexes: i) Online Service (SOS), ii) ICT infrastructure (STI) and iii) Human Capital (SHC). The first component of EGDI based on the breadth of online services available on national websites such as government portals and websites of ministries for education, labor, social services, health, finance, and environment. The second component is based on the International Telecommunication Union (ITU)'s ICT Development Index (IDI). The telecommunication infrastructure factor consists of measures for internet users, main fixed-phone lines, mobile subscribers, fixed broadband subscriptions, and wireless broadband subscriptions. A personal computer index has been replaced by an index of fixed internet subscriptions for the 2012 edition of the
UN E-Government Survey, and this component in turn was exchanged for an index of wireless broadband subscriptions in the UN E-Government Survey 2014. The last component is related to the ability to use e-government. Unfortunately, there is no worldwide e-awareness index that directly measures the ability to use e-government. Instead, the most of studies in this field uses adult literacy and the gross enrollment of primary, secondary, and tertiary schools as a proxy indicator in line with the UN EGovernment Survey. In the UN E-Government Survey 2014, expected years of education and mean years of schooling are included in the human capital index.

B. Measurement of e-government development

Gross domestic product (GDP) per capita is used to indicate a country's level of economic development. The data is sourced from the World Bank [WB]. GDP per capita based on purchasing power parity (PPP). PPP GDP is gross domestic product converted to international dollars using purchasing power parity rates. An international dollar has the same purchasing power over GDP as the U.S. dollar has in the United States. GDP at purchaser's prices is the sum of gross value added by all resident producers in the economy plus any product taxes and minus any subsidies not included in the value of the products. It is calculated without making deductions for depreciation of fabricated assets or for depletion and degradation of natural resources. Data are in constant 2011 international dollars [WB].

\section{Measurement of social development}

The research approach adopts two World Bank [WB] government indicators: i) the policy and institutions for environmental sustainability rating and ii) the public-sector management and institutions cluster both bases on CPIA (Country Policy and Institutional Assessment) survey. The CPIA exercise is intended to capture the quality of a country's policies and institutional arrangements, focusing on key elements that are within the country's control, rather than on outcomes (such as economic growth rates) that are influenced by events beyond the country's control. More specifically, the CPIA measures the extent to which a country's policy and institutional framework supports sustainable growth and poverty reduction and, consequently, the effective use of development assistance. Policy and institutions for environmental sustainability assess the extent to which environmental policies foster the protection and sustainable use of natural resources and the management of pollution. The public sector management and institutions cluster includes property rights and rule-based governance, quality of budgetary and financial management, efficiency of revenue mobilization, quality of public administration, and transparency, accountability, and corruption in the public sector. By data availability 
issues was used a Latin-American average on these components, except by Bolivia.

D. Measurement of environment sustainability

CO2 emissions ( $\mathrm{kg}$ per $2011 \mathrm{PPP}$ \$ of GDP) is used to indicate a country's level of environmental sustainability. Carbon dioxide emissions are those stemming from the burning of fossil fuels and the manufacture of cement. They include carbon dioxide produced during consumption of solid, liquid, and gas fuels and gas flaring [WB]. This specific index is a proxy of how an Economy pollutes in order to generate a unit of GDP.

\section{RESULTS AND DISCUSSION}

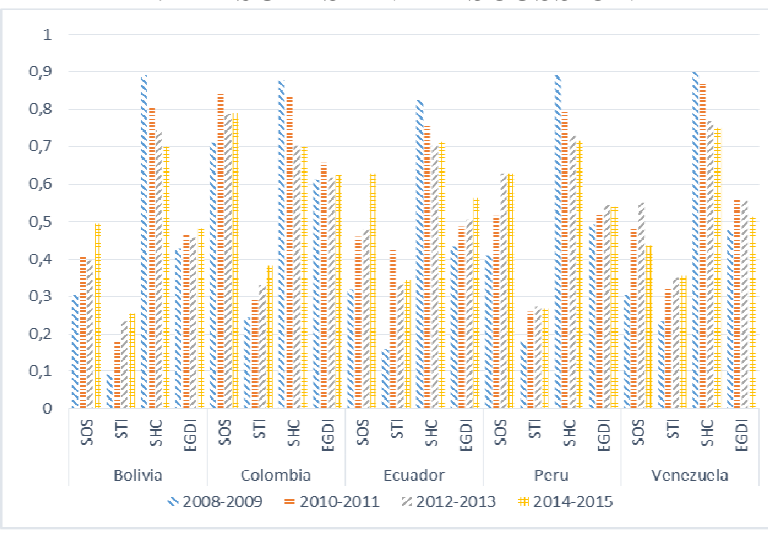

Fig. 2. EGDI evolution in Andeans Countries (2008-2015)

Colombia is the country with the highest EGDI average value in the region (0.63). However, Ecuador is that most developed with a rate grow average of $8.35 \%$ (see Fig. 2). Strategies for improving the technological infrastructure are limited by economic factor in the region, however, regarding to Online Service Colombia has been the leader in the region with the highest SOS average value (0.78), but Ecuador has presented the best improvements by the analysis period with a rate grow average of $19.72 \%$. Ecuador has the highest STI average value in the region (0.32), but Bolivia has presented the best improvements by the analysis period with a rate grow average of $26.71 \%$. Human Capital has been important in the implementation of e-government strategies, Venezuela has remained in the top positions in the process of evaluating this factor $(0.82)$, note that in the entire region suffered a setback in this SHC indicator.

It is identified that the strategies adopted by Ecuador have significantly contributed to its location within the references in progress of e-government in the region, the momentum that has been given to government portals in this country has allowed a more participatory society in the development of public policy, making citizens affirm the perception of transparency and closeness of government to the citizen (see Figure 2).
Table 1.

Correlation Matrix (Pearson) for Ecuador

\begin{tabular}{|c|c|c|c|c|c|c|c|c|}
\hline Variables & SOS & STI & SHC & EGDI & $\begin{array}{c}\text { GDP- } \\
\text { pc }\end{array}$ & $\begin{array}{c}\text { CPIA- } \\
1 \\
\end{array}$ & $\begin{array}{c}\text { CPIA- } \\
2 \\
\end{array}$ & $\begin{array}{l}\text { CO2/ } \\
\text { USD }\end{array}$ \\
\hline SOS & 1 & 0.625 & $\begin{array}{c}- \\
0.841 \\
-\end{array}$ & 0.998 & 0.915 & -0.854 & -0.951 & -0.576 \\
\hline STI & $\begin{array}{c}0.625 \\
-\end{array}$ & $\begin{array}{l}1 \\
-\end{array}$ & 0.689 & $\begin{array}{c}0.603 \\
-\end{array}$ & $\begin{array}{c}0.439 \\
-\end{array}$ & -0.627 & -0.367 & 0.257 \\
\hline SHC & 0.841 & 0.689 & $\begin{array}{l}1 \\
-\end{array}$ & 0.865 & 0.917 & 0.996 & 0.792 & 0.424 \\
\hline EGDI & 0.998 & 0.603 & $\begin{array}{c}0.865 \\
-\end{array}$ & 1 & 0.940 & -0.880 & -0.963 & -0.608 \\
\hline GDP-pc & $\begin{array}{c}0.915 \\
-\end{array}$ & $\begin{array}{c}0.439 \\
-\end{array}$ & 0.917 & $\begin{array}{c}0.940 \\
-\end{array}$ & $\begin{array}{l}1 \\
-\end{array}$ & -0.946 & -0.958 & -0.738 \\
\hline CPIA-1 & $\begin{array}{c}0.854 \\
-\end{array}$ & $\begin{array}{c}0.627 \\
-\end{array}$ & 0.996 & $\begin{array}{c}0.880 \\
-\end{array}$ & $\begin{array}{c}0.946 \\
-\end{array}$ & 1 & 0.831 & 0.504 \\
\hline CPIA-2 & $\begin{array}{c}0.951 \\
-\end{array}$ & 0.367 & 0.792 & $\begin{array}{c}0.963 \\
-\end{array}$ & $\begin{array}{c}0.958 \\
-\end{array}$ & 0.831 & 1 & 0.800 \\
\hline $\mathrm{CO} 2 / \mathrm{USD}$ & 0.576 & 0.257 & 0.424 & 0.608 & 0.738 & 0.504 & 0.800 & 1 \\
\hline
\end{tabular}

Table 1 shows that Ecuadorian e-government development indices exhibit a strong correlation, whether positive or negative, with economic and social development indices as well as environment development indices. The EGDI show the highest magnitude of correlation with the economic develop indices (GDP-pc $=0$.940) and negative correlation with the environmental index $(\mathrm{CO} 2 / \mathrm{USD}=-0.608)$. The above is in concordance with the approach of Egovernment for Sustainable Development (see Fig. 3 and Fig. 4). Nevertheless the finding show a negative correlation between EGDI and the two social develop index that has been used. Note that EGDI is a composite index, so that, the major contribute to the dynamic above is due to SOS correlation with the correspondent indicators (GDP-pc $=0.915$ and $\mathrm{CO} 2 / \mathrm{USD}=-0.576$ )

Colombia has begun the implementation phase of technology projects focused on citizens, many of the efforts involving simplifying procedures and automation to generate concrete benefits for citizens through online services (see Figure 2).

Table 2.

Correlation Matrix (Pearson) for Colombia

\begin{tabular}{|c|c|c|c|c|c|c|c|c|}
\hline Variables & SOS & STI & SHC & EGDI & $\begin{array}{c}\text { GDP- } \\
\text { pc }\end{array}$ & $\begin{array}{c}\text { CPIA- } \\
1 \\
\end{array}$ & $\begin{array}{c}\text { CPIA- } \\
2 \\
\end{array}$ & $\mathrm{CO} 2 / \mathrm{USD}$ \\
\hline SOS & 1 & 0,438 & 0,305 & 0,848 & 0,372 & $-0,544$ & $-0,269$ & 0,430 \\
\hline STI & 0,438 & 1 & $0,927^{-}$ & $0,018^{-}$ & 0,996 & $-0,914$ & $-0,979$ & 0,999 \\
\hline SHC & $0,305^{-}$ & 0,927 & 1 & 0,234 & $0,948^{-}$ & 0,963 & 0,894 & $-0,943$ \\
\hline EGDI & 0,848 & 0,018 & 0,234 & 1 & 0,101 & $-0,022$ & 0,159 & $-0,040$ \\
\hline GDP-pc & $\begin{array}{r}0,372 \\
-\end{array}$ & $\begin{array}{r}0,996 \\
-\end{array}$ & 0,948 & 0,101 & 1 & $-0,917$ & $-0,984$ & 0,998 \\
\hline CPIA-1 & $\begin{array}{r}0,544 \\
-\end{array}$ & $\begin{array}{r}0,914 \\
\text { - }\end{array}$ & 0,963 & 0,022 & $\begin{array}{r}0,917 \\
\text {. }\end{array}$ & 1 & 0,831 & $-0,928$ \\
\hline CPIA-2 & 0,269 & 0,979 & $\begin{array}{r}0,894 \\
-\end{array}$ & $\begin{array}{r}0,159 \\
-\end{array}$ & 0,984 & 0,831 & 1 & $-0,976$ \\
\hline $\mathrm{CO} 2 / \mathrm{USD}$ & 0,430 & 0,999 & 0,943 & 0,040 & 0,998 & $-0,928$ & $-0,976$ & \\
\hline
\end{tabular}
alpha $=0.05$

Table 2 shows that although Colombia historically leads the EDGI in the region, this country has not been the highest developed in the studied period. 
Environment. Technology. Resources, Rezekne, Latvia Proceedings of the $11^{\text {th }}$ International Scientific and Practical Conference. Volume I, 13-19

Therefore, the EGDI does not show significant correlation with the economic develop index (GDP$\mathrm{pc}=-0.101)$ and with the environmental index $(\mathrm{CO} 2 /$ USD $=-0.004)$. Besides, the finding show a no correlation between EGDI and the two social develop indices that have been used. Note that there is a significant and contradictory correlation between STI and SHC with the rest of indices. The above show that in Colombia case the finding not support the approach of E-government for Sustainable Development.

Peru has a consolidated organizational structure that allows articulate directly on issues of government policy to implement e-government projects; however, the limitations of this country are generated by citizens' access to technology tools (see Table. 3 ).

Table 3.

Correlation Matrix (Pearson) for Peru

\begin{tabular}{|c|c|c|c|c|c|c|c|c|}
\hline Variables & SOS & STI & SHC & EGDI & $\begin{array}{c}\text { GDP- } \\
\text { pc }\end{array}$ & $\begin{array}{c}\text { CPIA- } \\
1\end{array}$ & $\begin{array}{c}\text { CPIA- } \\
2 \\
\end{array}$ & $\mathrm{CO} 2 / \mathrm{USD}$ \\
\hline SOS & 1 & 0,919 & $0,9 \overline{-}$ & 0,983 & 0,981 & $-0,999$ & $-0,860$ & $-0,762$ \\
\hline STI & 0,919 & 1 & 0,947 & 0,967 & 0,872 & $-0,931$ & $-0,691$ & $-0,453$ \\
\hline SHC & 0,993 & $0,947^{-}$ & 1 & 0,984 & $0,98 \overline{-}$ & 0,992 & 0,866 & 0,714 \\
\hline EGDI & 0,983 & 0,967 & 0,984 & 1 & 0,938 & $-0,991$ & $-0,767$ & $-0,635$ \\
\hline GDP-pc & 0,981 & 0,872 & 0,982 & $\begin{array}{r}0,938 \\
\text { - }\end{array}$ & 1 & $-0,970$ & $-0,941$ & $-0,822$ \\
\hline CPIA-1 & $\begin{array}{r}0,999 \\
-\end{array}$ & 0,931 & 0,992 & 0,991 & $\begin{array}{r}0,970 \\
-\end{array}$ & 1 & 0,831 & 0,734 \\
\hline CPIA-2 & $\begin{array}{r}0,860 \\
-\end{array}$ & $\begin{array}{r}0,691 \\
-\end{array}$ & 0,866 & $\begin{array}{r}0,767 \\
-\end{array}$ & $\begin{array}{r}0,941 \\
-\end{array}$ & 0,831 & 1 & 0,881 \\
\hline $\mathrm{CO} 2 / \mathrm{USD}$ & 0,762 & 0,453 & 0,714 & 0,635 & 0,822 & 0,734 & 0,881 & 1 \\
\hline
\end{tabular}

Table 3 shows that Peru's e-government development indices exhibit a strong correlation, whether positive or negative, with economic and social development indices as well as environment development indices. The EGDI show the highest magnitude of correlation with the economic develop index (GDP-pc $=0$.938) and negative correlation with the environmental index (CO2/USD $=-0.635)$. The above is in concordance with the approach of Egovernment for Sustainable Development (see Fig. 3 and Fig. 4). Nevertheless the finding show a negative correlation between EGDI and the two social develop indices that has been used. Note that EGDI is a composite index, so that, the major contribute to the dynamic above is due to SOS correlation with the correspondent indicators (GDP-pc $=0.981$ and $\mathrm{CO} 2 / \mathrm{USD}=-0.762$ ) .

Venezuela has managed its governmental structure with regulatory mechanisms to imposing enforce implementation strategies, however, the positioning obtained within EGDI assessment is directly linked to the subscript of Human Capital (see Figure 2).
Table 4.

CORRELATION MATRIX (PEARSON) FOR VENEZUELA

\begin{tabular}{|c|c|c|c|c|c|c|c|c|}
\hline Variables & SOS & STI & SHC & EGDI & $\begin{array}{c}\text { GDP- } \\
\text { pc }\end{array}$ & $\begin{array}{c}\text { CPIA- } \\
1 \\
\end{array}$ & $\begin{array}{c}\text { CPIA- } \\
2 \\
\end{array}$ & $\begin{array}{l}\mathrm{CO} 2 / \\
\mathrm{USD} \\
\end{array}$ \\
\hline SOS & 1 & 0,855 & 0,605 & 0,944 & $0,87 \overline{4}^{-}$ & $-0,819$ & $-0,375$ & 0,200 \\
\hline STI & 0,855 & 1 & 0,859 & 0,724 & 0,968 & $-0,967$ & $-0,781$ & 0,011 \\
\hline SHC & 0,605 & 0,859 & 1 & 0,336 & 0,704 & 0,948 & 0,929 & 0,519 \\
\hline EGDI & 0,944 & 0,724 & 0,336 & 1 & 0,825 & $-0,616$ & $-0,136$ & 0,510 \\
\hline GDP-pc & 0,874 & 0,968 & 0,704 & 0,825 & 1 & 0,875 & 0,644 & 0,241 \\
\hline CPIA-1 & $\begin{array}{r}0,819 \\
\text { - }\end{array}$ & 0,967 & 0,948 & 0,616 & 0,875 & 1 & 0,831 & 0,250 \\
\hline CPIA-2 & 0,375 & $\begin{array}{r}0,781 \\
-\end{array}$ & 0,929 & 0,136 & $\begin{array}{r}0,644 \\
-\end{array}$ & 0,831 & 1 & 0,476 \\
\hline CO2/USD & 0,200 & 0,011 & 0,519 & 0,510 & 0,241 & 0,250 & 0,476 & 1 \\
\hline
\end{tabular}

Table 4 shows that although Venezuela historically leads the GDP-pc in the region, this are not related with a progress in improvement in governance, social (negative correlation) neither environmental (positive correlation) aspects of the development and its economic develop is due to Venezuela's enormous wealth of natural resources (petroleum). Besides, the finding show that SHC has high correlation with the economic and social index that has been used. The above is in concordance with the approach of E-government for Sustainable Development (see Fig. 3 and Fig. 4).

Bolivia has worked in the development of the National Governance Program (PRONAGOB), where the state is a facilitator and manager of the sectors of society work in partnership and integration in decision-making; it has not been managed by government agencies, which has led to limited progress in this regard (see Fig. 2).

Table 5 .

Correlation Matrix (Pearson) for Bolivia

\begin{tabular}{lrrrrrrrrr}
\hline \multirow{2}{*}{ Variables } & SOS & STI & SHC & EGDI & pc & 1 & 2 & CO2/USD \\
\hline \multirow{2}{*}{ SOS } & $\mathbf{1}$ & 0,889 & 0,906 & $\mathbf{0 , 9 8 9}$ & 0,915 & 0,914 & $-0,914$ & 0,857 \\
& & & - & & & & & \\
STI & 0,889 & $\mathbf{1}$ & $\mathbf{0 , 9 9 3}$ & 0,878 & 0,750 & $\mathbf{0 , 9 6 4}$ & $\mathbf{- 0 , 9 6 4}$ & $\mathbf{0 , 9 5 7}$ \\
& - & - & & - & - & & & \\
SHC & 0,906 & $\mathbf{0 , 9 9 3}$ & $\mathbf{1}$ & 0,879 & 0,814 & $\mathbf{- 0 , 9 8 9}$ & $\mathbf{0 , 9 8 9}$ & $\mathbf{- 0 , 9 8 3}$ \\
EGDI & $\mathbf{0 , 9 8 9}$ & 0,878 & 0,879 & $\mathbf{1}$ & 0,851 & 0,869 & $-0,869$ & 0,805 \\
GDP-pc & 0,915 & 0,750 & 0,814 & 0,851 & $\mathbf{1}$ & 0,879 & $-0,879$ & 0,836 \\
CPIA-1 & 0,914 & $\mathbf{0 , 9 6 4}$ & $\mathbf{0 , 9 8 9}$ & 0,869 & 0,879 & $\mathbf{1}$ & $\mathbf{- 1 , 0 0 0}$ & $\mathbf{0 , 9 9 3}$ \\
& - & - & & - & - & & & \\
CPIA-2 & 0,914 & $\mathbf{0 , 9 6 4}$ & $\mathbf{0 , 9 8 9}$ & 0,869 & 0,879 & $\mathbf{- 1 , 0 0 0}$ & $\mathbf{1}$ & $\mathbf{- 0 , 9 9 3}$ \\
& & & - & & & & & \\
CO2/USD & 0,857 & $\mathbf{0 , 9 5 7}$ & $\mathbf{0 , 9 8 3}$ & 0,805 & 0,836 & $\mathbf{0 , 9 9 3}$ & $\mathbf{- 0 , 9 9 3}$ & $\mathbf{1}$ \\
\hline Values in
\end{tabular}

in bold are significantly different from 0 with a significance level alpha $=0.05$

Table 5 shows that Bolivia's e-government development indices exhibit a strong correlation, whether positive or negative, with economic and social development indices as well as environment development indices. The EGDI show the highest magnitude of correlation with the economic develop 
index (GDP-pc $=0$.851) and with one of the social index (CPIA-1 = 0.869). The above is in concordance with the approach of E-government for economic and social development (see Fig. 3 and Fig. 4). Nevertheless the finding show a negative correlation between EGDI and the other social develop indices and a positive correlation with the environmental index that has been used.

\section{CORRELATION} MATRIX(PEARSON):

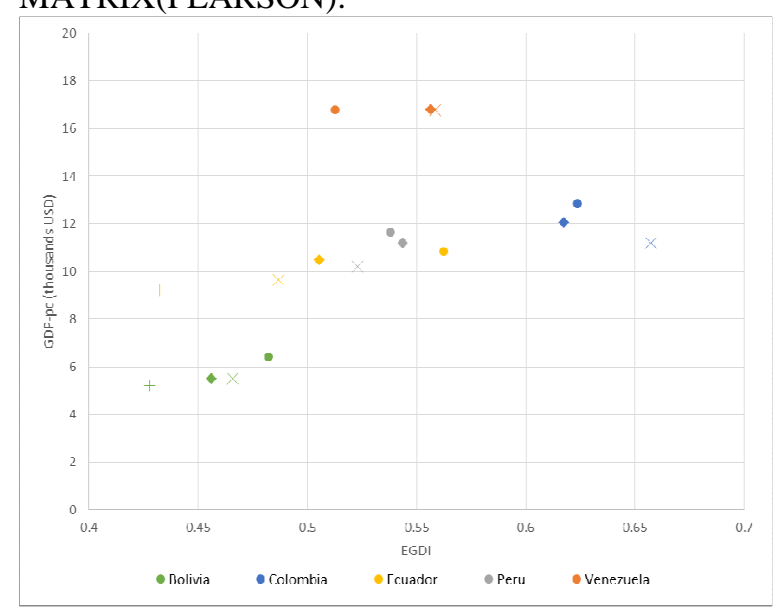

Fig. 3. Scatter plot of GDP per capita vs. EGDI (2008-2015). Scatter plot of GDP per capita vs. EGDI (2008-2015). Cross marks correspond to $\mathrm{P} 1, \mathrm{X}$ marks correspond to $\mathrm{P} 2$, diamond marks correspond to $\mathrm{P} 3$ and circle marks correspond to $\mathrm{P} 4$.

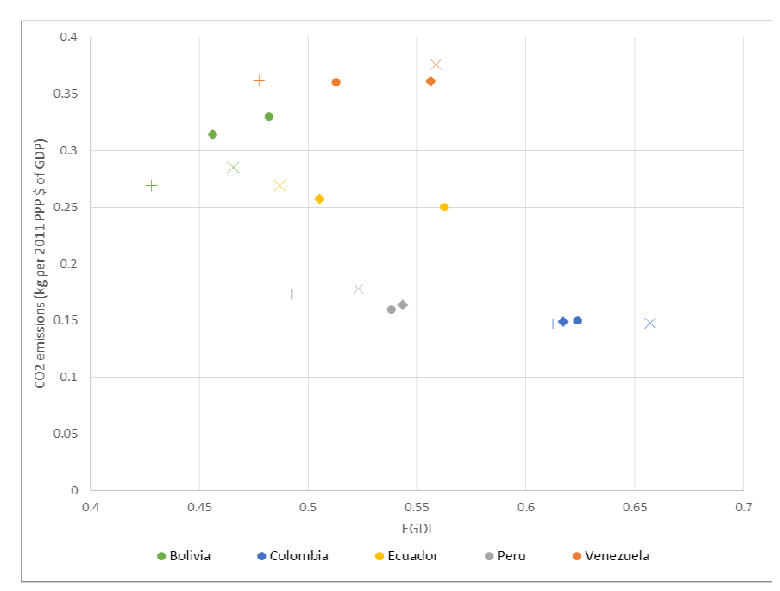

Fig. 4. Scatter plot of CO2 emissions (kg per 2011 PPP \$ of GDP) vs. EGDI (2008-2015). Scatter plot of GDP per capita vs. EGDI (2008-2015). Cross marks correspond to P1, X marks correspond to $\mathrm{P} 2$, diamond marks correspond to $\mathrm{P} 3$ and circle marks correspond to $\mathrm{P} 4$.

\section{CONCLUSION}

Taking as a reference the indicator of egovernment development, EGDI proposed by UNDESA it was attempted to identify and describe the progress of the Andean countries and the strategies implemented during the period 2008-2015 as development policies of government management. The aim of this study was to analyze the relationship of EGDI with a so called Sustainable Development (social, economic and environmental). The finding shows that two countries (Ecuador and Peru) had strong correlation between an e-governance developed and sustainable develop (social, economic and environmental). However, Colombia is the country with the highest EGDI average value in the region (0.63). But, Ecuador is that most developed with a rate grow average of $8.35 \%$ on the studied period.

The biggest overall progress by the ranking provided by the EGDI evidenced by certain countries by the region is due to the development of different actions and strategies by each of the sub-indexes so that in the case of online services, Colombia, Ecuador and Peru at the end of the studied period were those that optimized the use of electronic channels for the completion of formalities including more than obtaining information and services, participation in decision-making in public policy.

The results indicate that e-government development fosters a more capable and transparent government and contribute to lead to sustainable development in terms of economic, social, and environmental development. This study also identified some key factors of successful egovernment development in Andeans countries by a correlational and comparative analysis.

Among them, the results show that evidenced benefits that have been obtained in mainstreaming egovernment strategy in each of the countries of this study were: i) the transformation of the obsolete administration to the efficient and transparent management; ii) Improved quality of services provided; iii) Reduction of bureaucracy and strengthening capacities of the population; iv) optimization of state resources and improving response times in the procedures required by citizen; v) a substantial improvement in terms of responsiveness and answering the needs of citizens by public institutions; vi) transparent and streamlined processes within the government apparatus which generates trust and cooperation from the citizenry; vii) creation and / or improvement of accountability processes; iix) establishment and strengthening of spaces and mechanisms for citizen participation in decision making that directly affect the benefit of the community. Based on these findings, this study suggest the following policy recommendations for sustainable development of Andeans countries thorough the advancement of e-government: i) Continuous political commitment to e-government development. ii) ICT/E-government infrastructures for sustainable development. iii) International cooperation and Andean platform of e-government development.

\section{V.ACKNOWLEDGMENTS}

This study was partly supported by the Escuela Politécnica Nacional (EPN) of Ecuador. Research Project No PIJ-16-10. 


\section{REFERENCES}

[1] D.L. Rabina, "United Nations Global E-Government Readiness Report 2005: From E-Government to E-Inclusion. New York: Department of Economic and Social Affairs," in Government Information Quarterly, vol.24, 2007, pp.903904.

[2] C. Sproles, "Trends in Sustainable Development. Department of Economic and Social Affairs, Division for Sustainable Development. United Nations," in Government Information Quarterly, vol.25, 2008, pp.337-338.

[3] Y.B. Lee, "E-Government for Promoting Sustainable Development in Small Island Developing States (SIDS)", in Background Paper For the Special Event of the 69th Session of the United Nations General Assembly Second Committee, 2014.

[4] H. Choi, M. J. Park, J. J. Rho, H. Zo, "Rethinking the assessment of e-government implementation in developing countries from the perspective of the design-reality gap: Applications in the Indonesian e-procurement system," in Telecommunications Policy, vol.40, 2016, pp. 644.-660

[5] D. L. Baker, "Advancing e-government performance in the United States through enhanced usability benchmarks," in Government Information Quarterly, vol.26, 2016, pp. 82-88.

[6] Department of Agriculture, Government of Sri Lanka, "Official Department of Agriculture, Government of Sri Lanka Webpage". 2017, available online: https://www.doa.gov.lk/index.php/en/

[7] Government Digital Service in United Kingdom, "Gov.uk". 2017, available online: https://www.gov.uk/government/organizations/governmentdigital-service

[8] Seoul Metropolitan Government, "Eco Mileage Program". 2017, available online: https://seulsolution.krwww.gov.uk

[9] F. Sá, Á. Rocha, M. P. Cota, "From the quality of traditional services to the quality of local e-Government online services: A literature review," in Government Information Quarterly, vol. 33, 2016, pp.149-160.

[10] D. Arduini, M. Denni, M. Lucchese, A. Nurra, A. Zanfei, "The role of technology, organization and contextual factors in the development of e-Government services: An empirical analysis on Italian Local Public Administrations," in Structural change and Economic Dynamics, vol. 27, 2013, pp.177-189.

[11] E. Bonsón, L. Torres, S. Royo, F. Flores, „Local egovernment 2.0: Social media and corporate transparency in municipalities," in Government Information Quarterly, vol. 29, 2012,pp. 123-132.
[12] H. Zhang, X. Xu, J. Xiao, "Diffusion of e-government: A literature review and directions for future directions," in Government Information Quarterly, vol. 31, 2014, pp.631636.

[13] United Nations Department of Economic and Social Affairs, "Estudio de las Naciones Unidas sobre el Gobierno Electrónico," 2012, avaliable online https://publicadministration.un.org/egovkb/Portals/egovkb/D ocuments/un/2012-Survey/Complete-Survey-Spanish2012.pdf

[14] A. Ayanso, D. Chatterjee, D. I. Cho, "E-Government readiness index: A methodology and analysis," in Government Information Quarterly, vol. 28, 2011, pp. 522532.

[15] United Nations Department of Economic and Social Affairs, "E-government Survey 2012 e-government for the people," 2012, pp.164, available online https://publicadministration.un.org/egovkb/Portals/egovkb/D ocuments/un/2012-Survey/unpan048065.pdf

[16] World Bank, "World Development Indicators (WDI)", 2016, available online http://datacatalog.worldbank.org

[17] A. Robalino-López, J.E. García-Ramos, Antonio A. Golpe, A. Mena-Nieto, "CO2 emissions convergence among 10 South American countries. A study of Kaya components (1980-2010)," in Carbon Management, vol.7, 2016, pp 1-12.

[18] United Nations Department of Economic and Social Affairs, "E-government Survey 2010 leveraginge-government at a time of financial and economic crisis," 2010, pp.124, available online https://publicadministration.un.org/egovkb/portals/egovkb/do cuments/un/2010-survey/complete-survey.pdf

[19] United Nations Department of Economic and Social Affairs Division for Public Administration and Development Management, "E-government Survey 2014," 2014, available online https://publicadministration.un.org/egovkb/enus/reports/un-e-government-survey-2014

[20] United Nations Department of Economic and Social Affairs Division for Public Administration and Development Management, "E-government Survey 2016," 2016, available online https://publicadministration.un.org/egovkb/enus/reports/un-e-government-survey-2016 
Zanna Aniscenko, et al./ Environment. Technology. Resources, (2017), Volume I, 13-19 
Environment. Technology. Resources, Rezekne, Latvia Proceedings of the $11^{\text {th }}$ International Scientific and Practical Conference. Volume I, 13-19 